\title{
Effects of Tillage Methods and Nitrogen Fertilizer on Soil Properties and Performance of Yellow Oleander in Southern Nigeria
}

\author{
Aboyeji Christopher Muyiwa ${ }^{1 *}$, Adekiya Aruna Olasekan ${ }^{1}$, Dunsin Oluwagbenga ${ }^{1}$, Aduloju Morolake \\ $\mathrm{O}^{1}$, Olofintoye Temidayo A. Joseph ${ }^{2}$, Olugbemi Oluwatoyin ${ }^{3}$ \\ 1. Department of Crop and Soil Science, College of Agricultural Sciences, Landmark University, P.M.B 1004, Omu-aran, \\ Nigeria. \\ 2. National Horticultural Research Institute (NIHORT), P.M.B 5432, Ibadan, Nigeria \\ 3. Department of Agronomy, University of Ilorin, P.M.B 1515, Ilorin \\ *Corresponding Author email: chrismuyiwa@yahoo.com
}

\begin{tabular}{|c|c|}
\hline Paper Information & A B S T R A C T \\
\hline & A study was conducted at the Research Farms of Biofuel Alternate and \\
\hline Received: 12 March, 2016 & $\begin{array}{l}\text { Renewable Energy Ltd, Edidi, Kwara State, Nigeria. Zero tillage, } \\
\text { ploughing once and ploughing + harrowing and three rates of nitrogen }\end{array}$ \\
\hline Accepted: 27 May, 2016 & fertilizer $\left(0,30,60 \mathrm{Kg} \mathrm{ha}^{-1}\right.$ Urea) were evaluated to assess their effect on \\
\hline & soil physical and chemical properties and performance of Yellow Oleander \\
\hline \multirow[t]{10}{*}{ Published: 2 July, 2016} & (Thevetia peruviana (Pers.) Schum.). The experiment, designed as $3 \times 3$ \\
\hline & factorial and fitted into randomized complete block design (RCBD) was \\
\hline & laid out in split-plots and replicated four times. Ploughing once as against \\
\hline & $\begin{array}{l}\text { zero tillage and ploughıng + harrowing produced higher values for plant } \\
\text { height, number of primary branches, kernel number, kernel weight, N, P, }\end{array}$ \\
\hline & $\mathrm{K}, \mathrm{Ca}$ and $\mathrm{Mg}$. The performance of ploughing once treatment was related \\
\hline & $\begin{array}{l}\text { to higher soil nutrient. Nitrogen fertilizer improved significantly the } \\
\text { growth and yield of Thevetia when compared with the control. There were }\end{array}$ \\
\hline & no significant difference in number and weight of kernel at $30 \mathrm{~kg} \mathrm{~N} \mathrm{ha}^{-1}$ \\
\hline & and $60 \mathrm{~kg} \mathrm{~N} \mathrm{ha}^{-1}$. Due to the rising cost of fertilizer, ploughing once and \\
\hline & application of $30 \mathrm{~kg} \mathrm{~N} \mathrm{ha}^{-1}$ is recommended for Thevetia production in \\
\hline & Nigerian southern guinea savanna. \\
\hline
\end{tabular}

Key words: Tillage methods, Soil properties, Nitrogen fertilizer, Kernel yield and Thevetia

\section{Introduction}

Soil tillage is one of the agricultural production methods that is of extreme importance to both rural and urban farmers. Sustainable food production has therefore been linked to different agricultural production techniques. Lal, (1995) defined soil tillage as physical, chemical or biological soil manipulation to optimize conditions for germination, seedling establishment and crop growth. Some of the objectives of tilling the soil include seedbed preparation, water and soil conservation, erosion and weed control.

FAO-IITA, (2000) reported that retaining crop residues on the soil surface with conservation tillage reduces evapotranspiration, increases infiltration rates, and suppresses weed growth. Conservation agriculture (CA) technologies reduce soil disturbance and retain crop residues can minimize soil evaporation and soil erosion losses, increase nutrient use efficiency, and reduce energy requirements for crop establishment compared with conventional tillage (Sayre and Hobbs, 2004: Lal et al., 2007).

Tillage loosens the soil and buries crop residue; which leaves the soil vulnerable to pounding rain and strong winds, which are both contributing factors to erosion (Lal et al., 2007). When the soil surface dries after excessive tillage, a heavy rain can create a crust that makes germination, emergence and crop establishment difficult (Lal et al., 2007).

Thevetia peruviana (Pers) Schum. is an evergreen tropical arborescent shrub in the family Apocynaceae of the order Gentianales. It is commonly known as Yellow oleander (nerium), Lucky nut, Be-still tree, gum bush, bush milk, exile tree in India, Cabalonga in Puerto Rico and Olomi ojo by the Yorubas of Nigeria. It grows readily in the wild. In spite of the high oil content $(67 \%)$ of its kernel (Azam et al., 2005) and favourable protein content (37\%) in de-oil cake (Ibiyemi et al., 2007), it has remained only an ornamental, fencing or wasteland plant in Nigeria.

Ibiyemi et al. (2007) produced quality and sizable bio-diesel from T. peruviana seeds and reported that the shrub has a wider range of uses than some tree borne oil seeds such as physic nut (Jatropha curcas), castor-oil plant (Ricinus communis) and neem (Azadirachta indica) which have been identified and widely used as potential source of quality biodiesel. 
Tillage induces nutrient release, decomposition of organic matter and mineralization of organic nutrients (Ojeniyi, 1992). However, intensive tillage causes rapid degradation of soil physical, chemical and biological qualities (Lal, (1995), hence there is need to establish tillage recommendation for Thevetia. In the same vein, soil tillage and application of soil amendment in soil management practices is one of the cardinal points to increasing crop yield.

Tillage practices play vital role on crop establishment, growth and development, as intensive tillage causes greater soil and nutrient erosion (Subbulakshmi, 2009). Nitrogen is frequently the most limiting essential nutrient in natural ecosystems (Tilman, 2002). Insufficient nitrogen typically limits plant growth in nature and plants merely slow their growth to fit the available supply of nitrogen (Aboyeji and Abayomi, 2013a). Nitrogen is a major nutritional element required for tissue differentiation and its role in increasing plant growth and development are well documented by various workers (Aziz, 2007; Shedeed, 1986).

The response of Thevetia to $\mathrm{N}$ fertilizer application and different tillage systems had not been investigated, however, farmers have to know the rate of application of fertilizers.

The present study centered on the evaluation of the possibilities of employing the combination of different tillage methods and application of varying rates of nitrogen fertilizer for sustainable cropping of Thevetia on Alfisol of Nigeria southern Guinea savanna.

\section{Materials And Methods \\ Description of the experimental site}

The research was conducted during the 2013 and 2014 cropping seasons at the Research Farms of the Biofuels Alternate and Renewable Energy Ltd, Edidi, Kwara State, Nigeria to assess the effect of different tillage systems and application of varying rates of nitrogen fertilizer on soil properties and the performance of Thevetia peruviana in Nigeria southern guinea savanna. Edidi lies between Latitude $8^{\circ} 14^{\prime} \mathrm{N}$, Longitude $4^{\circ} 56^{\prime} \mathrm{E}$ and on an elevation of $447 \mathrm{~m}$ above sea level. As usual rainfall started in March and ended in October or early November with a break of about two weeks either in July or August. Edidi has an average annual rainfall of between $1000 \mathrm{~mm}-1400 \mathrm{~mm}$ which is peculiar to the southern Guinea savanna areas. On the average there are about $6-7$ rainy days per month, usually between May and October. The total annual rainfall in 2014 was higher than that of 2013, even though the monthly rainfall distributions for the two years were similar.

The dry season started from November and ended by February/March of the following year. The annual rainfall during 2013 and 2014 were $1036 \mathrm{~mm}$ and 1449mm respectively. The climatic conditions during the experimental periods are presented on Tables 1 and 2 for 2013 and 2014 respectively. The soil of the experimental site is an Alfisols classified as Oxic Haplustalf (USDA) or luvisol (FAO). Composite upper soil layer $(0-15 \mathrm{~cm})$ samples from the experimental sites were taken to determine the physical and chemical properties of the soil before cropping. A variety of crops were grown at the sites including maize (Zea mays L.), guinea corn (Sorghum bicor L. Moench), soybean (Glycine max L.) and various leafy vegetables consecutively for seven years without fertilizer application before the initiation of this study.

\section{Treatment and experimental design}

The experiment consisted of three tillage systems- zero tillage, ploughing once and ploughing + harrowing and three rates of nitrogen fertilizer $\left(0,30,60 \mathrm{Kg} \mathrm{N} \mathrm{ha}^{-1}\right)$. The experimental design was a factorial in Randomized Complete Block with split-plot arrangement model and replicated four times.

\section{Plot size and land preparation}

The size of each main plot in the experiment was $12 \mathrm{~m} \mathrm{x} 12 \mathrm{~m}$ while that of the sub-plot was $4 \mathrm{~m} \times 12 \mathrm{~m}$. Alleyways between each main plot and between each replicates were $3 \mathrm{~m}$. Each main plot was then tilled based on the assigned treatment (zero tillage, ploughing once and ploughing + harrowing). The number of plants in each sub-plot was 12 plants while each main plot contained 36 plants at a spacing of $2 \mathrm{~m}$ x $2 \mathrm{~m}$. Borders were made across each sub-plot to prevent seepage.

Disc ploughing and harrowing were carried out to an average depth of $20 \mathrm{~cm}$ with a disc plough and harrow mounted separately on STEYR 768 tractor of 51.5kw. In the zero tillage treatments, the existing weeds were destroyed using a systemic herbicide (Glyphosate) applied at 4 liters/ha. Operations for the three tillage methods were carried out within the first and second week of May 2013 and 2014 respectively.

\section{Determination of soil properties}

Prior to the commencement of the experiment in 2013 and 2014, soil samples were taken from 0 to $15 \mathrm{~cm}$ depths from each site. The samples were put in an oven set at $100^{\circ} \mathrm{C}$ for $24 \mathrm{~h}$ for determination of bulk density. Total porosity was calculated from bulk density using particle density of $2.65 \mathrm{~g} / \mathrm{cm}^{3}$. The soil samples were also bulked, air-dried and sieved using a $2 \mathrm{~mm}$ sieve and analysed for particle-size, soil organic matter, total $\mathrm{N}$, available $\mathrm{P}$, exchangeable $\mathrm{K}, \mathrm{Ca}$ and $\mathrm{Mg}$, and $\mathrm{p}^{\mathrm{H}}$. At the end of the experiment, soil samples were also taken for routine soil analysis on plot basis. Samples were analysed as described by P (Pansu and Gautheyrou, 2006). Particle-size analysis was done using hydrometer method (Gee and Or, 2002). The organic matter was determined by the procedure of Walkley and Black using the dichromate wet oxidation method (Nelson and Sommers, 1992). Total N was determined by micro-Kjeldahl digestion method (Bremner, 1996), available P was determined by Bray-1 extraction followed by molybdenum blue colorimetry (Frank, 1998). 
Exchangeable $\mathrm{K}, \mathrm{Ca}$ and $\mathrm{Mg}$ were extracted using ammonium acetate, $\mathrm{K}$ level was determined using a flame photometer, and $\mathrm{Ca}$ and $\mathrm{Mg}$ by the EDTA titration method

Two weeks after transplanting, determination of soil physical properties in all plots commenced and this was done at monthly interval on five occasions for each year. Five undisturbed samples (4 cm diameter, $10 \mathrm{~cm}$ high) were collected at 0-15 cm depth from each plot using core soil sampler and were used for the evaluation of bulk density (Campbell and Henshall, 1991) and gravimetric moisture content after oven dried at $100^{\circ} \mathrm{C}$ for 24 hours. Soil temperature was determined at 15.00 hours with a soil thermometer inserted to $5 \mathrm{~cm}$ depth. Five readings were made per plot at each sampling time and the mean data were computed.

\section{Nursery/Transplanting}

The seeds were pre-germinated in a covered and protected nursery in plastic bags for 6 weeks before they were transplanted to the field at a spacing of $2 \mathrm{~m}$ by $2 \mathrm{~m}$ on the flat. The total plant population was 2,500 plants ha ${ }^{-1}$

The seeds for the year 2013 experiment were sown on the $2^{\text {nd }}$ of April, 2013 and transplanted on the 21st of May, 2013, while the seeds for the year 2014 experiment were sown and transplanted on the $6^{\text {th }}$ of April, 2014 and $25^{\text {th }}$ of May, 2014 respectively.

\section{Fertilizer application}

For each of the tillage treatments, nitrogen fertilizer in form of Urea $(46 \% \mathrm{~N})$ was applied at the rate of 0,30 and $60 \mathrm{~kg} \mathrm{~N} \mathrm{ha}^{-1}$ in two split doses. The first dose of 0,15 and $30 \mathrm{~kg} \mathrm{~N} \mathrm{ha}^{-1}$ was applied at 2 weeks after transplanting (WAT) while the second dose of 0,15 and $30 \mathrm{~kg} \mathrm{~N} \mathrm{ha}^{-1}$ was applied at 6 WAT by side placements at about $8-10 \mathrm{~cm}$ away from the base of the plant.

\section{Weed control}

Glyphosate a systemic and non-selective herbicide was used at the rate of $2.5 \mathrm{~kg}^{\mathrm{a} . \mathrm{i}} \mathrm{ha}^{-1}$ at intervals 6,18 and 26 weeks after transplanting using Knapsack sprayer to control both annual and perennial weeds. The herbicide was carefully applied so that it does not contact with any green part of the tree, including the trunk.

\section{Harvesting}

Mature fruits were manually collected after reaching maturity stage as indicated by the black colour of the succulent outer covering. The succulent outer covering of the seeds were removed and the seeds dried, counted and weighed separately per plot.

\section{Data collection}

The following parameters were collected during the two years of the research work.

Plant height $(\mathrm{cm})$ : - The heights of five tagged plants per plot were measured at 8, 16 and 24 weeks after transplanting, using meter rule from ground level to the tip of the highest growing point, and the mean recorded.

Number of primary branches: - This was determined at intervals of 8,16 and 24 WAT by counting the numbers of branches that were $5 \mathrm{~cm}$ long and above in length that emerged directly from the main stem from each of the five tagged plants per plot and the mean recorded.

Number of kernels harvested $\left(\mathrm{ha}^{-1}\right)$ : - Harvested mature seeds were counted per plot and the mean value recorded as number of seeds per hectare.

Dry weight of 10 seeds per plot $(\mathrm{kg})$ : - After harvest and drying of the seeds for 3 days, 10 seeds were randomly picked from each plot, weighed and recorded per hectare.

\section{Data analysis}

The data collected were subjected to analysis of variance (ANOVA) using Statistical Analysis Software (SAS, 2000) and the significant treatment means were compared using the Duncan's multiple range test $(\mathrm{DMRT})$ at $\mathrm{p}=0.05$ probability level.

\section{Results}

\section{Initial soil physical and chemical status of the sites before experimentation}

The results show that the sites are sandy loam, high in sand and bulk density, slightly acidic, low inorganic matter, $\mathrm{N}, \mathrm{P}$ and $\mathrm{Ca}$ but adequate in $\mathrm{K}$ and $\mathrm{Mg}$ (Table 3).

\section{Effect of tillage methods and Nitrogen fertilizer application on soil physical and chemical properties}

Tillage methods influenced soil physical properties significantly (Table 4). Zero tillage has the highest values of bulk density and ploughing + harrowing the least. There was no significant difference between ploughing once and ploughing + harrowing. Tillage methods also influence the soil moisture content significantly. The order was zero tillage $>$ ploughing once $>$ ploughing + harrowing. However, in both years, ploughing + harrowing had significantly higher values of temperature while zero tillage had the least value. 
Nitrogen fertilizer applications do not influence soil physical properties significantly in both years. There was no significant interaction between tillage methods and rates of applied nitrogen fertilizer on bulk density, moisture content and soil temperature in the two years of the experiment.

Table 5 shows the result of the effect of tillage methods and nitrogen fertilizer application on soil chemical properties in 2013 and 2014 cropping seasons. The results show that tillage methods significantly influence N, P, K, Ca and $\mathrm{Mg}$ in both years with ploughing once having the highest value and ploughing + harrowing the least. The order was ploughing once $>$ zero tillage $>$ ploughing + harrowing. There was no significant difference in the values of organic matter between ploughing once, zero tillage and ploughing + harrowing. The mean values of organic matter for zero tillage, ploughing once and ploughing + harrowing were respectively, 2.47, 2.48 and 2.42. The value of $\mathrm{N}$ for zero tillage, ploughing once and ploughing + harrowing was $0.16,0.19$ and 0.12 respectively. Phosphorus had the mean values of 5.7, 6.6 and 4.8 for zero tillage, ploughing once and ploughing + harrowing respectively. Mean K for zero tillage, ploughing once and ploughing + harrowing were $0.15,0.17$ and 0.13 respectively while $\mathrm{Ca}$ and $\mathrm{Mg}$ values for zero tillage, ploughing once and ploughing + harrowing were respectively, $1.52,1.80,1.26$ and $0.58,0.75,0.47$ respectively.

Nitrogen fertilizer in form of Urea also positively influenced soil chemical properties compared with no application. In 2013, $30 \mathrm{~kg} / \mathrm{ha}$ urea significantly produced higher values of $\mathrm{N}, \mathrm{P}, \mathrm{K}, \mathrm{Ca}$ and $\mathrm{Mg}$ compared with no application. The values of soil chemical properties recorded by $30 \mathrm{~kg} / \mathrm{ha}$ was not statistically different from that of 60 $\mathrm{kg} / \mathrm{ha}$ Nitrogen fertilizer. The values of soil organic matter were also not significantly different between the control and other treatments.

The interaction between tillage methods and rates of nitrogen fertilizer was not significant on organic matter in both years and on total nitrogen in 2013. There was significant interaction effect of tillage methods and rates of nitrogen fertilizer on total nitrogen in 2014 and available phosphorus and exchangeable cations in both years.

\section{Effect of tillage methods and Nitrogen fertilizer application on plant height}

Zero tillage and harrowing once plots positively influenced the plant height in both years and at all sampling periods but the difference in the values of the tillage systems were not significant at 16 and 24 weeks after transplanting (WAT) in 2013. Ploughing + Harrowing tillage method gave shorter plant height while the difference in the height of plants on zero tillage and harrowing once plots was not significant, though ploughing once had taller plant height.

When nitrogen fertilizer was applied in either year, significant difference in plant height was first observed at 16 weeks after transplanting (WAT) in both years. Application of $30 \mathrm{~kg} \mathrm{~N} \mathrm{ha}^{-1}$ showed significant increase in plant height when compared with the control. There was no significant difference in plant height when nitrogen fertilizer was increased from $30 \mathrm{~kg} \mathrm{~N}^{-1}$ to $60 \mathrm{~kg} \mathrm{~N}^{-1}$.

The interaction effect between tillage methods and rates of nitrogen fertilizer on plant height was only significant at 16 and 24 WAT in 2014.

\section{Effect of tillage methods and Nitrogen fertilizer application on number of primary branches}

In both years and at all sampling periods, formation of branches was more rapid on ploughing once plot but did not differ statistically with zero tillage while plants on ploughing + harrowing plots produced a significantly lower number of branches. Application of $60 \mathrm{~kg} \mathrm{~N} \mathrm{ha}^{-1}$ also produced more number of branches; the values did not differ significantly with the application of $30 \mathrm{~kg} \mathrm{~N} \mathrm{ha}^{-1}$. Control nitrogen fertilizer $\left(0 \mathrm{~kg} \mathrm{~N} \mathrm{ha}^{-1}\right)$ produced a significantly lower number of primary branches in both years and at all sampling periods (Table 7).

In both years and at all sampling periods, there was a significant interaction effect of tillage methods and rates of nitrogen fertilizer on number of primary branches.

\section{Kernel number and weight}

Effects of tillage systems and application of nitrogen fertilizer on kernel number and kernel weight per plot $\left(\mathrm{kg}^{-1}\right)$ of Thevetia peruviana in 2013 and 2014 cropping seasons is shown on Table 8. Tillage systems significantly influenced kernel number and weight in both years. Kernel number and weight were significantly higher on ploughing once plots compared with zero tillage methods and ploughing + harrowing plots. Using the mean of the two years, ploughing once increased number of kernel by 14 and $38 \%$ and weight of kernel by 11 and $79 \%$ when compared with zero tillage and ploughing + harrowing.

Application of $30 \mathrm{~kg} \mathrm{~N}^{-1}$ significantly increased kernel yield and weight but when nitrogen rate was increased from $30 \mathrm{~kg} \mathrm{~N} \mathrm{ha}^{-1}$ to $60 \mathrm{~kg} \mathrm{~N} \mathrm{ha}^{-1}$ a relatively much lower increment was observed. The control $\left(0 \mathrm{~kg} \mathrm{~N} \mathrm{ha}^{-1}\right) \mathrm{gave}^{\mathrm{a}}$ significantly lower yield and weight during the two cropping seasons. Using the mean and compared with the control, 30 $\mathrm{kg} \mathrm{N} \mathrm{ha}^{-1}$ increased kernel number of Thevetia by $37 \%$ while $60 \mathrm{~kg} \mathrm{~N}^{-1}$ increased Thevetia kernel number by $40 \%$. Likewise, $30 \mathrm{~kg} \mathrm{~N} \mathrm{ha}^{-1}$ increased Thevetia kernel weight by $69 \%$ and $60 \mathrm{~kg} \mathrm{~N} \mathrm{ha}^{-1}$ increased kernel weight by $70 \%$ (Table 8).

The effect of the interaction between tillage methods and application of rates of nitrogen fertilizer was significant on number and weight of kernel.

Table 9 shows the correlation coefficient between mean values of soil physical and chemical properties and performance parameters of Thevetia. The results showed that soil physical properties (bulk density, moisture content and soil temperature) do not significantly influenced performance parameters. Though not significant, bulk density and 
moisture content were positive and soil temperature negative. However, soil chemical properties (organic matter, N, P, K, $\mathrm{Ca}$ and $\mathrm{Mg}$ ) influenced plant height, branches, kernel number and weight of Thevetia significantly, except for $\mathrm{Ca}$ and $\mathrm{Mg}$ for kernel number and kernel weight.

\section{Discussion}

Effect of tillage methods and Nitrogen fertilizer application on soil physical and chemical properties

The higher bulk density of zero tillage compared with ploughing once and ploughing + harrowing could be attributed to non-tillage and soil compaction. This means that continuous exposure of untilled soil to rainfall without mechanical tillage compact the soil. Zero tillage had higher moisture and lower temperature compared with other tillage methods, this could be related to organic matter in the soil surface which acted as mulch to reduce temperature and evaporation loss of water. The higher moisture content in zero tilled soil can also be adduced to the killed vegetation which acted like mulch on the surface of the soil to reduce temperature and conserve soil water and preventing evaporation.

The result also showed that ploughing + harrowing had higher temperature and lower moisture content compared with ploughing once because of greater soil tilt produced by ploughing + harrowing which increase turbulent movement of atmospheric air into it which would have enhanced water evaporation and raised temperature compared with ploughing once where the surface is rough.

Tillage enhances mineralization of soil organic matter. The result that $\mathrm{N}, \mathrm{P}, \mathrm{K}, \mathrm{Ca}$ and $\mathrm{Mg}$ were higher in ploughing once compared with zero tillage could be due to the enhanced mineralization of organic matter and consequent release of nutrients. The decline in the nutrient reserves of ploughing + harrowing compared with zero tillage could be as a result of soil erosion that removes colloidal fraction with high 'enrichment ratio' resulting in a progressive depletion of its nutrient reserves. Ploughing once produced higher values of soil $\mathrm{N}, \mathrm{P}, \mathrm{K}, \mathrm{Ca}$ and $\mathrm{Mg}$ compared with ploughing + harrowing. This was due to minimal disturbance of soil by this treatment compared with ploughed followed by harrowed soil.

Increase in $\mathrm{N}, \mathrm{P}, \mathrm{K}, \mathrm{Ca}$ and $\mathrm{Mg}$ due to application of Nitrogen fertilizer could be adduced to decomposition of soil organic matter and mineralization of its nutrients.

Table 1: Meteorological data of the experimental site for 2013

\begin{tabular}{|c|c|c|c|c|c|}
\hline & $\begin{array}{l}\text { Rainfall } \\
(\mathrm{mm})\end{array}$ & $\frac{\text { Temperature }\left({ }^{\circ} \mathrm{c}\right)}{\text { Min }}$ & $\frac{\text { Sunshine hours }}{\text { Max }}$ & No. of rainfall days & /Month \\
\hline Jan & 0.00 & 19.16 & 33.45 & 230.15 & 00 \\
\hline Feb & 6.5 & 23.61 & 35.39 & 182.25 & 01 \\
\hline Mar & 60.9 & 24.74 & 35.58 & 148.50 & 04 \\
\hline Apr & 58.2 & 24.30 & 35.30 & 199.45 & 05 \\
\hline May & 115.5 & 24.10 & 32.03 & 187.80 & 08 \\
\hline Jun & 45.1 & 22.17 & 31.30 & 142.07 & 07 \\
\hline Jul & 139.1 & 22.19 & 28.45 & 88.91 & 13 \\
\hline Aug & 123.7 & 21.94 & 28.58 & 90.55 & 15 \\
\hline Sept & 218.2 & 21.73 & 29.30 & 116.95 & 20 \\
\hline Oct & 267.1 & 21.61 & 30.55 & 179.95 & 18 \\
\hline Nov & 2.0 & 21.00 & 32.90 & 232.35 & 01 \\
\hline Dec & 0.00 & 18.26 & 32.81 & 266.35 & 00 \\
\hline Total & 1036.3 & 264.8 & 385.64 & 2065.28 & 92 \\
\hline Mean & 86.34 & 22.34 & 32.14 & 172.11 & 7.7 \\
\hline
\end{tabular}

Source: Meteorological station, Lower Niger River Basin Development Authority, Ilorin

Table 2: Meteorological data of the experimental site for 2014

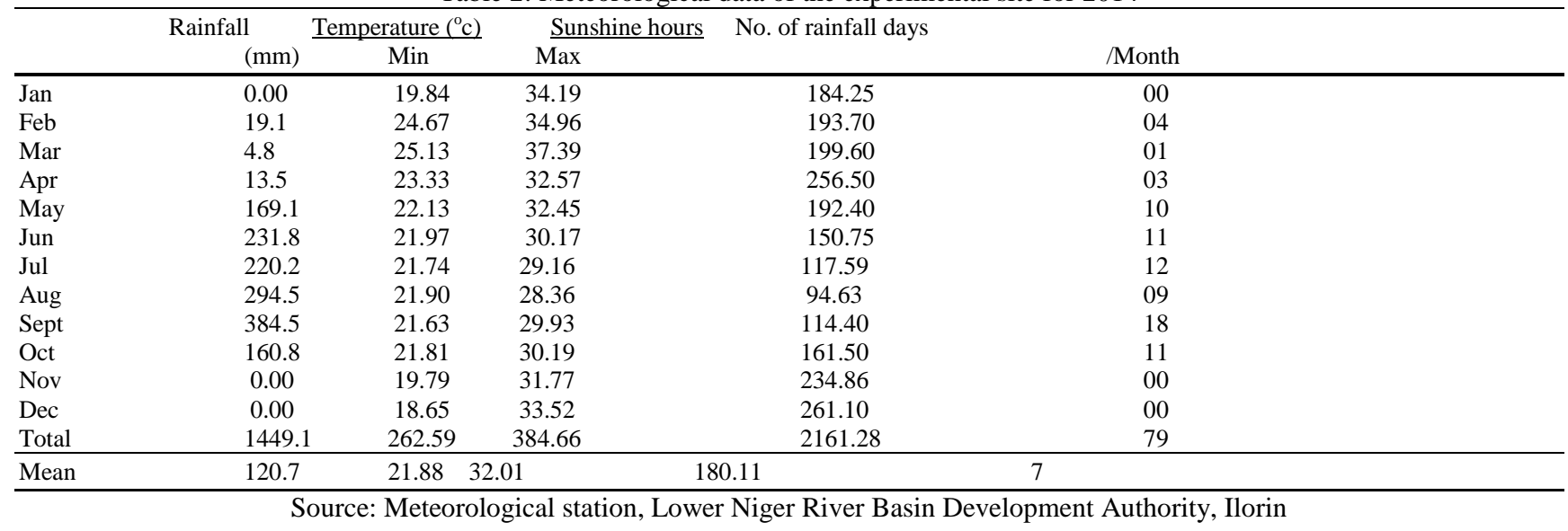


Table 3: Initial soil physical and chemical status of the sites before experimentation

\begin{tabular}{lll}
\hline Property & 2013 & 2014 \\
\hline Sand (\%) & 68 & 69 \\
Silt $(\%)$ & 14 & 14 \\
Clay $(\%)$ & 18 & 17 \\
Textural class & Sandyloam & Sandyloam \\
Bulk density & 1.55 & 1.55 \\
Porosity & 41.4 & 41.4 \\
$\mathrm{pH}($ water $)$ & 5.8 & 5.8 \\
Organic matter $(\%)$ & 2.49 & 2.86 \\
Total N (\%) & 0.18 & 0.19 \\
Available $\mathrm{P}(\mathrm{mg} / \mathrm{kg})$ & 7.5 & 7.8 \\
Exchangeable K (cmol/kg) & 0.16 & 0.18 \\
Exchangeable Ca $(\mathrm{cmol} / \mathrm{kg})$ & 1.75 & 1.88 \\
Exchangeable $\mathrm{Mg}(\mathrm{cmol} / \mathrm{kg})$ & 0.63 & 0.77 \\
\hline
\end{tabular}

Table 4: Effect of tillage methods and Nitrogen fertilizer application on soil physical properties

\begin{tabular}{|c|c|c|c|c|c|c|c|c|c|}
\hline Treatments & \multicolumn{3}{|c|}{ Bulk density $\left(\mathrm{g} \mathrm{cm}^{-3}\right)$} & \multicolumn{3}{|c|}{ Moisture content (\%) } & \multicolumn{3}{|c|}{ Soil Temp. $\left({ }^{\circ} \mathrm{C}\right)$} \\
\hline Tillage methods & 2013 & 2014 & Mean & 2013 & 2014 & Mean & 2013 & 2014 & Mean \\
\hline Zero tillage & $1.55 \mathrm{a}$ & $1.56 \mathrm{a}$ & 1.56 & $16.4 \mathrm{a}$ & $20.7 \mathrm{a}$ & 18.6 & $28.5 \mathrm{c}$ & $27.1 \mathrm{c}$ & 27.8 \\
\hline Ploughing once & $1.25 \mathrm{~b}$ & $1.25 \mathrm{~b}$ & 1.25 & $13.3 b$ & $17.7 \mathrm{~b}$ & 15.5 & $30.1 b$ & $29.0 \mathrm{~b}$ & 29.6 \\
\hline $\begin{array}{l}\text { Ploughing +harrowing } \\
\text { Nitrogen rate }\left(\mathrm{kg} \mathrm{N} \mathrm{ha}^{-1}\right)\end{array}$ & $1.20 \mathrm{~b}$ & $1.20 \mathrm{~b}$ & 1.20 & $11.1 \mathrm{c}$ & $14.1 \mathrm{c}$ & 12.6 & $33.0 \mathrm{a}$ & $32.2 \mathrm{a}$ & 32.6 \\
\hline 0 & $1.33 \mathrm{a}$ & $1.34 \mathrm{a}$ & & $16.4 \mathrm{a}$ & $20.7 \mathrm{a}$ & & $28.5 \mathrm{a}$ & $27.1 \mathrm{a}$ & \\
\hline 30 & $1.33 \mathrm{a}$ & $1.34 \mathrm{a}$ & & $16.4 \mathrm{a}$ & $20.7 \mathrm{a}$ & & $28.5 \mathrm{a}$ & $27.1 \mathrm{a}$ & \\
\hline $\begin{array}{l}60 \\
\text { Interaction }\end{array}$ & $1.33 \mathrm{a}$ & $1.34 \mathrm{a}$ & & $16.4 \mathrm{a}$ & $20.7 \mathrm{a}$ & & $28.5 \mathrm{a}$ & $27.1 \mathrm{a}$ & \\
\hline $\mathrm{TXN}$ & Ns & Ns & & Ns & Ns & & Ns & Ns & \\
\hline
\end{tabular}

Values followed by similar letters within the same column are not significantly different according to Duncan's multiple range test (DMTR)

Table 5: Effect of tillage methods and Nitrogen fertilizer application on soil chemical properties

\begin{tabular}{|c|c|c|c|c|c|c|c|c|c|c|c|c|}
\hline \multirow[b]{2}{*}{ Tillage methods } & \multirow{2}{*}{$\begin{array}{l}\text { Organic } \\
(\%)\end{array}$} & \multirow{2}{*}{$\begin{array}{l}\text { matter } \\
2014\end{array}$} & \multicolumn{2}{|c|}{ Total N (\%) } & \multicolumn{2}{|c|}{ Avail.P (mg/kg) } & \multicolumn{2}{|c|}{ Exch K (cmol/kg) } & \multicolumn{2}{|c|}{$\begin{array}{l}\text { Exch } \\
(\mathrm{cmol} / \mathrm{kg})\end{array}$} & \multicolumn{2}{|c|}{$\begin{array}{l}\text { Exch } \\
(\mathrm{cmol} / \mathrm{kg})\end{array}$} \\
\hline & & & 2013 & 2014 & 2013 & 2014 & 2013 & 2014 & 2013 & 2014 & 2013 & 2014 \\
\hline Zero tillage & $2.45 \mathrm{a}$ & $2.49 \mathrm{a}$ & $0.16 b$ & $0.15 b$ & $5.2 b$ & $6.2 b$ & $0.14 \mathrm{~b}$ & $0.15 b$ & $1.48 \mathrm{~b}$ & $1.56 \mathrm{~b}$ & $0.54 \mathrm{~b}$ & $0.61 \mathrm{~b}$ \\
\hline Ploughing once & $2.50 \mathrm{a}$ & $2.51 \mathrm{a}$ & $0.18 \mathrm{a}$ & $0.19 \mathrm{a}$ & $6.0 \mathrm{a}$ & 7.1a & $0.16 \mathrm{a}$ & $0.17 \mathrm{a}$ & $1.70 \mathrm{a}$ & $1.89 \mathrm{a}$ & $0.70 \mathrm{a}$ & $0.80 \mathrm{a}$ \\
\hline $\begin{array}{l}\text { Ploughing + harrowing } \\
\text { Nitrogen rate }\left(\mathrm{kg} \mathrm{N} \mathrm{ha}^{-1}\right)\end{array}$ & $2.40 \mathrm{~b}$ & $2.41 \mathrm{~b}$ & $0.12 \mathrm{c}$ & $0.12 \mathrm{c}$ & $4.3 \mathrm{c}$ & $5.3 b$ & $0.12 \mathrm{c}$ & $0.13 \mathrm{c}$ & $1.20 \mathrm{c}$ & $1.32 \mathrm{c}$ & $0.41 \mathrm{c}$ & $0.53 \mathrm{c}$ \\
\hline 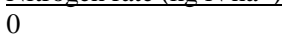 & $2.45 \mathrm{a}$ & $2.46 \mathrm{a}$ & $0.15 \mathrm{a}$ & $0.15 b$ & $5.2 \mathrm{~b}$ & $6.2 \mathrm{~b}$ & $0.14 b$ & $0.15 \mathrm{c}$ & $1.46 \mathrm{~b}$ & $1.59 \mathrm{~b}$ & $0.55 \mathrm{~b}$ & $0.65 b$ \\
\hline 30 & $2.40 \mathrm{a}$ & $2.47 \mathrm{a}$ & $0.16 a$ & $0.18 \mathrm{a}$ & $6.8 \mathrm{a}$ & 7.9a & $0.17 \mathrm{a}$ & $0.18 \mathrm{ab}$ & $1.68 \mathrm{a}$ & $1.81 \mathrm{a}$ & $0.79 \mathrm{a}$ & $0.91 \mathrm{a}$ \\
\hline 60 & $2.47 \mathrm{a}$ & $2.44 \mathrm{a}$ & $0.16 \mathrm{a}$ & $0.18 \mathrm{a}$ & $7.2 \mathrm{a}$ & $8.0 \mathrm{a}$ & $0.18 \mathrm{a}$ & $0.20 \mathrm{a}$ & $1.69 \mathrm{a}$ & $1.85 \mathrm{a}$ & $0.81 \mathrm{a}$ & $0.91 \mathrm{a}$ \\
\hline Interaction & & & & & & & & & & & & \\
\hline $\mathrm{TXN}$ & Ns & Ns & Ns & $*$ & $*$ & $*$ & $*$ & $*$ & $*$ & $*$ & $*$ & $*$ \\
\hline
\end{tabular}

Values followed by similar letters within the same column are not significantly different according to Duncan's multiple range test (DMTR)

$$
*=\quad \text { significant at } 0.05 \text { level of probability } \quad \mathrm{NS}=\text { Not significant at } 0.05 \text { level of probability }
$$

Table 6: Effects of tillage methods and nitrogen fertilizer application on plant height (cm) of Thevetia peruviana in 2013 and 2014

\begin{tabular}{|c|c|c|c|c|c|c|c|}
\hline \multirow[b]{2}{*}{ Treatment } & \multicolumn{2}{|c|}{2013} & \multicolumn{4}{|c|}{2014} & \multirow[b]{3}{*}{ Mean } \\
\hline & $8 \mathrm{WAT}$ & 16WAT & 24WAT & $8 \mathrm{WAT}$ & 16WAT & 24WAT & \\
\hline \multicolumn{7}{|l|}{ Tillage methods } & \\
\hline Zero tillage & $41.12 \mathrm{a}$ & $72.04 \mathrm{a}$ & $90.09 \mathrm{a}$ & $46.21 \mathrm{ab}$ & $77.28 \mathrm{a}$ & $96.70 \mathrm{a}$ & 70.57 \\
\hline Ploughing once & $43.52 \mathrm{a}$ & $73.64 \mathrm{a}$ & $92.07 \mathrm{a}$ & $49.58 \mathrm{a}$ & $78.48 \mathrm{a}$ & $98.12 \mathrm{a}$ & 72.57 \\
\hline Ploughing + harrowing & $40.13 b$ & $71.40 \mathrm{a}$ & $89.49 \mathrm{a}$ & $45.01 \mathrm{~b}$ & $73.00 \mathrm{~b}$ & $91.18 \mathrm{~b}$ & 68.37 \\
\hline \multicolumn{8}{|l|}{ Nitrogen rate $\left(\mathrm{kg} \mathrm{N} \mathrm{ha}^{-1}\right)$} \\
\hline 0 & $40.93 \mathrm{a}$ & $70.00 \mathrm{~b}$ & $87.40 \mathrm{~b}$ & $44.79 \mathrm{a}$ & $75.11 \mathrm{~b}$ & $92.08 \mathrm{~b}$ & 68.38 \\
\hline 30 & $41.38 \mathrm{a}$ & $72.36 \mathrm{ab}$ & $90.38 \mathrm{ab}$ & $46.88 \mathrm{a}$ & $78.92 \mathrm{a}$ & $96.82 \mathrm{a}$ & 71.12 \\
\hline 60 & $42.47 \mathrm{a}$ & $74.73 \mathrm{a}$ & $93.40 \mathrm{a}$ & $47.73 \mathrm{a}$ & $79.78 \mathrm{a}$ & $98.08 \mathrm{a}$ & 72.69 \\
\hline \multicolumn{8}{|l|}{ Interaction } \\
\hline $\mathrm{TXN}$ & Ns & Ns & Ns & Ns & * & $*$ & \\
\hline
\end{tabular}

Values followed by the same letter(s) within the same column are not significantly different at $5 \%$ level of probability according to

$$
\begin{aligned}
& \text { Duncan's multiple range test (DMRT). } \\
& \text { WAT = Weeks after transplanting } \\
& * \quad=\quad \text { significant at } 0.05 \text { level of probability } \\
& \text { NS = Not significant at } 0.05 \text { level of probability }
\end{aligned}
$$

\section{Effect of tillage methods and Nitrogen fertilizer application on Thevetia growth and kernel yield}

Ploughing once compared with zero tillage and ploughing + harrowing increased Thevetia plant height, number of primary branches, kernel number and kernel weight per plot. The highest values of plant height, number of primary 
branches, kernel number and kernel weight under ploughing once was due to better soil condition resulting from this treatment which could be associated with better soil organic matter, $\mathrm{N}, \mathrm{P}, \mathrm{K}, \mathrm{Ca}$ and $\mathrm{Mg}$ (nutrient) of this treatment.

The correlation between soil chemical properties and performance parameters of Thevetia was significant and that of soil physical properties were not significant. This implies that soil chemical properties dictated the performance of Thevetia between zero, ploughing once and ploughing + harrowing. The soil physical properties (bulk density, moisture content and temperature) are not significant and suggest that they were not limiting for Thevetia production in the study area.

The application of nitrogen significantly increased the plant height, number of branches and girth of Thevetia. The significant effect caused by application of Nitrogen fertilizer to Thevetia plants showed that soil in these areas lack essential nutrients especially N. This is supported by the result of the physical and chemical properties of the sites before the experiments. There was no significant different between $30 \mathrm{~kg} / \mathrm{ha}$ and $60 \mathrm{~kg} / \mathrm{ha}$ nitrogen fertilizer for Thevetia plant. This means that above $30 \mathrm{~kg} / \mathrm{ha}, \mathrm{N}$ supply was at the luxury level and contributed less to yield. $30 \mathrm{~kg} / \mathrm{ha}$ nitrogen fertilizer seems to be adequate for Thevetia kernel yield.

Table 7: Effects of tillage methods and nitrogen fertilizer application on number of primary branches of Thevetia peruviana in 2013 and

\begin{tabular}{|c|c|c|c|c|c|c|c|}
\hline \multirow[b]{2}{*}{ Treatment } & \multicolumn{3}{|l|}{2013} & \multicolumn{3}{|l|}{2014} & \multirow[b]{3}{*}{ Mean } \\
\hline & 8WAT & 16WAT & 24WAT & 8WAT & 16WAT & 24WAT & \\
\hline Tillage methods (T) & & & & & & & \\
\hline Zero tillage & $9.93 \mathrm{ab}$ & $24.67 \mathrm{a}$ & $33.80 \mathrm{a}$ & $13.61 \mathrm{~b}$ & $29.80 \mathrm{ab}$ & $38.93 a$ & 25.12 \\
\hline Ploughing once & $10.69 \mathrm{a}$ & $27.71 \mathrm{a}$ & $35.60 \mathrm{a}$ & $16.38 \mathrm{a}$ & $31.69 \mathrm{a}$ & $39.80 \mathrm{a}$ & 26.98 \\
\hline $\begin{array}{l}\text { Ploughing + harrowing } \\
\text { Nitrogen rate }\left(\mathrm{kg} \mathrm{N} \mathrm{ha}^{-1}\right)\end{array}$ & $8.87 \mathrm{~b}$ & $22.70 \mathrm{~b}$ & $29.67 b$ & $15.93 \mathrm{a}$ & $27.71 \mathrm{~b}$ & $34.67 \mathrm{~b}$ & 23.25 \\
\hline 0 & $8.24 \mathrm{~b}$ & $22.87 \mathrm{~b}$ & $29.20 \mathrm{~b}$ & $13.87 \mathrm{~b}$ & $26.24 \mathrm{~b}$ & $33.24 b$ & \\
\hline 30 & $10.04 \mathrm{a}$ & $25.80 \mathrm{a}$ & $32.82 \mathrm{a}$ & $15.90 \mathrm{a}$ & $30.04 \mathrm{a}$ & $38.10 \mathrm{a}$ & 22.27 \\
\hline 60 & $10.47 \mathrm{a}$ & $25.47 \mathrm{a}$ & $33.04 \mathrm{a}$ & $16.21 \mathrm{a}$ & $30.47 \mathrm{a}$ & $38.80 \mathrm{a}$ & $\begin{array}{l}25.45 \\
25.74\end{array}$ \\
\hline Interaction & * & * & $*$ & $*$ & * & * & \\
\hline
\end{tabular}

Values followed by the same letter(s) within the same column are not significantly different at 5\% level of probability according to

Duncan's multiple range test (DMRT).

WAT $=$ Weeks after transplanting

$*=\quad$ significant at 0.05 level of probability

NS = Not significant at 0.05 level of probability

Table 8: Effects of tillage methods and nitrogen fertilizer application on kernel Number and kernel weight per plot $\left(\mathrm{kg}^{-1}\right)$ of Thevetia

\begin{tabular}{|c|c|c|c|c|c|c|}
\hline \multirow[b]{2}{*}{ Treatment } & \multicolumn{3}{|c|}{ Number of kernel $\quad\left(\mathrm{ha}^{-1}\right)$} & \multicolumn{2}{|c|}{ Kernel weight/ha (kg) } & \multirow[b]{3}{*}{ Mean } \\
\hline & 2013 & 2014 & & 2013 & 2014 & \\
\hline Tillage methods & & & Mean & & & \\
\hline Zero tillage & $3,722 \mathrm{~b}$ & $4,272 b$ & 7,994 & $21.22 \mathrm{~b}$ & $24.36 \mathrm{~b}$ & 45.58 \\
\hline Ploughing once & $4,294 \mathrm{a}$ & $4,844 \mathrm{a}$ & 9,138 & $23.88 \mathrm{a}$ & $26.94 \mathrm{a}$ & 50.82 \\
\hline $\begin{array}{l}\text { Ploughing + harrowing } \\
\text { Nitrogen rate }\left(\mathrm{kg} \mathrm{N} \mathrm{ha}^{-1}\right)\end{array}$ & $3,072 \mathrm{c}$ & $3,522 \mathrm{c}$ & 6,594 & $12.90 \mathrm{c}$ & $15.48 \mathrm{c}$ & 28.38 \\
\hline 0 & $2,994 \mathrm{~b}$ & $3,494 \mathrm{~b}$ & 3244 & $12.20 \mathrm{~b}$ & $14.48 \mathrm{~b}$ & \\
\hline 30 & $4,400 \mathrm{a}$ & $4,550 \mathrm{a}$ & 4475 & $21.88 \mathrm{a}$ & $23.14 \mathrm{a}$ & 13.34 \\
\hline 60 & $4,565 \mathrm{a}$ & $4,560 \mathrm{a}$ & 4562 & $22.07 \mathrm{a}$ & $23.52 \mathrm{a}$ & $\begin{array}{l}22.51 \\
2275\end{array}$ \\
\hline
\end{tabular}

Interaction

TXN

*

$$
\begin{array}{cc}
\text { Duncan's multiple range test (DMRT) } \\
\text { WAT }=
\end{array} \quad \begin{aligned}
& \text { Weeks after transplanting } \\
& \text { significant at } 0.05 \text { level of probability }
\end{aligned}
$$

\begin{tabular}{|c|c|c|c|c|c|c|c|c|c|}
\hline & $\begin{array}{l}\text { Bulk } \\
\text { density }\end{array}$ & $\begin{array}{l}\text { Moisture } \\
\text { content }\end{array}$ & $\begin{array}{l}\text { Soil } \\
\text { Temperature }\end{array}$ & $\begin{array}{l}\text { Organic } \\
\text { matter }\end{array}$ & $\mathrm{N}$ & $P$ & $\mathrm{~K}$ & $\mathrm{Ca}$ & $\mathrm{Mg}$ \\
\hline Plant height & $0.155^{\circ}$ & 0.507 & -0.640 & $0.993^{*}$ & $0.998 *$ & $0.998^{*}$ & $0.997^{*}$ & $0.999^{*}$ & $0.989^{*}$ \\
\hline Number of branches & 0.130 & 0.485 & -0.620 & $0.994^{*}$ & $0.997^{*}$ & $0.998^{* *}$ & $0.998^{* *}$ & $0.999^{*}$ & $0.992^{*}$ \\
\hline Kernel number & 0.185 & 0.537 & -0.663 & $0.993^{*}$ & $0.995^{*}$ & $0.998^{*}$ & $0.998^{*}$ & 0.997 & 0.984 \\
\hline Kernel weight & 0.413 & 0.722 & -0.822 & $0.998^{*}$ & $0.997^{*}$ & $0.996^{*}$ & $0.996^{*}$ & 0.949 & 0.912 \\
\hline
\end{tabular}

Table 9: Correlation coefficient between mean values of soil physical and chemical properties and performance parameters of Thevetia

$* *=$ correlation is significant at the 0.01 level

*= correlation is significant at the 0.05 level

\section{Conclusion}

Among the different tillage methods employed for the establishment of T. peruviana, ploughing once had higher values of plant height, number of primary branches, kernel number and weight soil organic matter, $\mathrm{N}, \mathrm{P}, \mathrm{K}, \mathrm{Ca}$ and $\mathrm{Mg}$ compared with zero tillage and ploughing + harrowing. The higher value of performance parameters under ploughing once 
treatments was adduced to high soil nutrient. Soil physical properties (bulk density, moisture content and temperature) were not limiting for Thevetia production in the study area. Nitrogen fertilizer improved significantly the growth and yield of Thevetia compared with the control. However, there was no significant different between $30 \mathrm{~kg} / \mathrm{ha}$ and $60 \mathrm{~kg} / \mathrm{ha}$ nitrogen fertilizer for Thevetia plant. $30 \mathrm{~kg} / \mathrm{ha}$ nitrogen fertilizer seems to be adequate for Thevetia production. With the rising cost of chemical fertilizer it can be said that ploughing once and application of $30 \mathrm{~kg} / \mathrm{ha}$ nitrogen fertilizer is recommended for the production of Thevetia peruviana in guinea savanna zone of Nigeria.

\section{References}

Adekiya AO, Agbede TM, Ojomo AO .2009. Effect of tillage methods on soil properties, nutrient content, growth and yield of tomato on an Alfisol of southwestern Nigeria. Am.Eurasian J Sustain Agr. 3 (3): pp. 348-353.

Akinrinde EA, Obigbesan GO. 2000. Evaluation of the fertility status of selected soils for Crop production in five ecological zones of Nigeria. Proceedings of the $26^{\text {th }}$ Annual Conference of Soil Science Society of Nigeria, Ibadan, Nigeria. Pp. 279-288.

Azam MM, Waris A, Nahar NM. 2005. Prospects and potential of fatty acid methyl esters of some non-traditional seed oils for use as biodiesel in India. Biomass and Bioenergy, 29, pp. 293-302.

Bremner IM. 1996. Nitrogen-total. In: Sparks, D.I. (Ed.). Methods of Soil Analysis. Part 3. Chemical Methods. $2^{\text {nd }}$ Edition SSSA Book series No. 5. ASA and SSSA, Madison, WI, USA, pp. 1085-1121.

Campbell DJ, Henshall JK. 1991. Bulk density. In: Smith, K.A. and Mullins, C.E.(Eds.). Physical Methods of s oil Analysis. Marcel Dekker, New York, pp.329-366.

FAO Land and Water Bulletin 8. FAO, Rome. ISBN 92-5-104417-1. pp. 214.

FAO-IITA (2000). Manual on integrated soil management and conservation practices.

Frank K, Beegle D, Denning J. 1988. Phosphorus. In: Brown, J.R. (Ed.), Recommended Chemical Soil Test Procedure for the North Central Region, Northcentral Region Research Publication No. 221 (revised ) Missouri Agric. Exp. Stn., Columbia, MO, pp. 21 - 26.

Gee GW, Or D. 2002. Particle-size Analysis. In: Dane, J.H., Topp, G.O. (Eds.), Methods of Soil Analysis. Part 4. Physical Methods. Soil Science Society of America, No. 5, Madison, Wisconsin, pp. 255-29.

Ibiyemi SA, Fadipe VO, Akinremi OO, Bako SS. 2002. Variation in oil composition of thevetia peruviana juss fruits seeds. J Appl. Sci. Environ. Management 6, (2), pp. 61-65.

Lal R, Kimble JM (1997). Conservation tillage for carbon sequestration. Nutrient Cycling Agroecosystem 49, pp. 243-25.

Lal R, Reicosky DC, Hanson JD. 2007. "Evolution of the plow over 10,000 years and the Rationale for no-till farming”. Soil and Tillage Research 93 (1), pp. 1-12.

Lal R. 1995. Tillage systems in the tropics: management options and sustainability Implications. FAO Soils Bulletin 71. FAO, Rome. ISBN 92-5103776. pp. 206

Nelson DW, Sommers LE. 1992. Total carbon, organic carbon and organic matter. In: Page, A. L., Miller, R.H. and Keeney; D.R. (Eds.). Methods of Soil Analysis, part 2. ASA, Madison WI, pp. 539- 580.

Ojeniyi SO. 1992. Food cropping, soil tillage and tillage research in sub-saharan Africa. Paper presented at Inaugural Seminar of ISTRO, Nigeria Branch, NCAM, Ilorin.

Pansu M, Gautheyrou J. 2006. Handbook of Soil Analysis. Mineralogical, Organic and Inorganic Methods. Springer-Verlag, Berlin Heidelberg, New York, pp. 995.

SAS. 2000. SAS User's Guide: Statistics. SAS Institute, Cary, NC.

Sayre K, Hobbs P. 2004. The raised-bed system of cultivation for irrigated production Conditions. In: Lal, R., Hobbs, P., Uphoff, N., Hansen, D. (Eds.), Sustainable Agriculture and the Rice-Wheat System. Ohio State University, Columbia, Ohio, USA, pp. 337-355.

Subbulakshmi S, Harisudan C, Saravanan CN, Subbian P. 2009. Conservation tillage - An ecofriendly management practices for agriculture. Research Journal of Agriculture and Biological Sciences 5 (6), pp. 1098-110.

Tilman D, Cassman KG, Naylor PAR, Polasky S. 2002. Agricultural sustainability and intensive production practices”. Nature 418, pp. 671-677. 